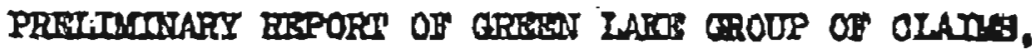 SIIPLS BAY, SITSA PEUSOTNCT, AIASKA \\ Norember 10, 1938.
}

\section{Locat1on and Aocoss1b111trt:}

The crean Lake group of olalms is looated at the hoad of S1lver Bay 10 mileg southeast of S1tka. Right lode 0laims and two mill sites oonstitute tho group; namely, Greon Lako Nos. 2, 2 and 3; Luckg Strike Nos. 1, 2 and 3 and the $B 1 g$ and Iittlo Chiet. One mill alte 18 located on tho besch and the othor 18 on the south ond of Green Lake below the creon. Iake tunnel. S1lrer Bey is navlgable for ocean going regsels with deop prater noarly to 1ts hood and has steoply rising shore Ifres, Ind loating depth. From the beach at the hoad a covermont tra1l loads orer a ridge, - levation 580 feot, and arops dopm to creon Lake, vlevetion 200 foot, over a Astanoe of lode then one intle.

Ormax:

This olatm toup is held by Stere Tug.

\section{B1storys}

The surfave shorlings on this eroup of olatms were discovered by Andrew Dlokgon in 1912. A fer alrface outs and some stripplag par done, rollowed later by a ohort tungel on one rein near the beach whloh 10 now caved. Following this work the property remained $1 \mathrm{~d}$ le and was roataked by $N$. Balghanin of S1tica and a short tunnel was started on the Ifttio Chlof olain prior to the etaking of tho property by stevo Tus in 1928. Tus started the Grean Iake tunnol during thds year under a largo quartz outolop on the surfigo and has been more or legs engaged in assessment work on this and other propertios in the rlolatty sinos that time,

\section{Q001085:}

On the date of the Friter's risit a hoavy fall of snow prerented the exmlnation of the sursace outs and the tunnel on the Ifttio Chief alaim. Samplos seen from the latter showlngs showed free gold in an oridized milky whlte quartz. High assayg wero reported by Tus from

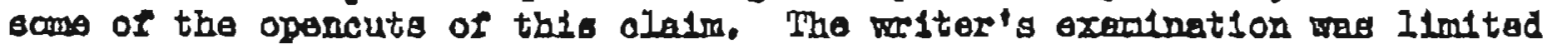
to tho oxemtration of the Groon Lake turnel and one out alongside the Green Lake tratl.

The geology of Silver bey, and ahort reports of prospects in the Vloinity, sre oontalued in U. 9. 0. 3. bullotin Ho. 504 by Adolph Knopf. The formations of this group conalat of interbodded graymole and slete, hloh strike N. $500 \mathrm{H.}$ and dis steoply to the mouth. Two parallal roins 300 fest apart, wth an ocosalonal autorop of quartz shoring along them, follow the formation in both otrits and dip. These veins were reported to be traceable over the entlre longth of the eroup. 
